\title{
Skjellsettende medisin
}

Det er alltid spennende å se tilbake på eldre reklameannonser. I 1940 (Tidsskr Nor Lægeforen 1940; 60: 1010) sto en reklame for Prontosil, som ble oppdaget i Tyskland i 1935. Dette er regnet som det første sulfapreparatet og hadde antibakteriell virkning mot bl.a. streptokokker. For denne oppdagelsen ble Gerhard Domagk (1895-1964) tildelt nobelprisen i fysiologi eller medisin i 1939, men Hitler nektet ham å ta imot prisen. Før de antibiotiske midlene ble tilgjengelig kunne en liten skramme føre til infeksjon og død, så det er kanskje ikke så rart at det i annonsen skrytes uhemmet av produktet.

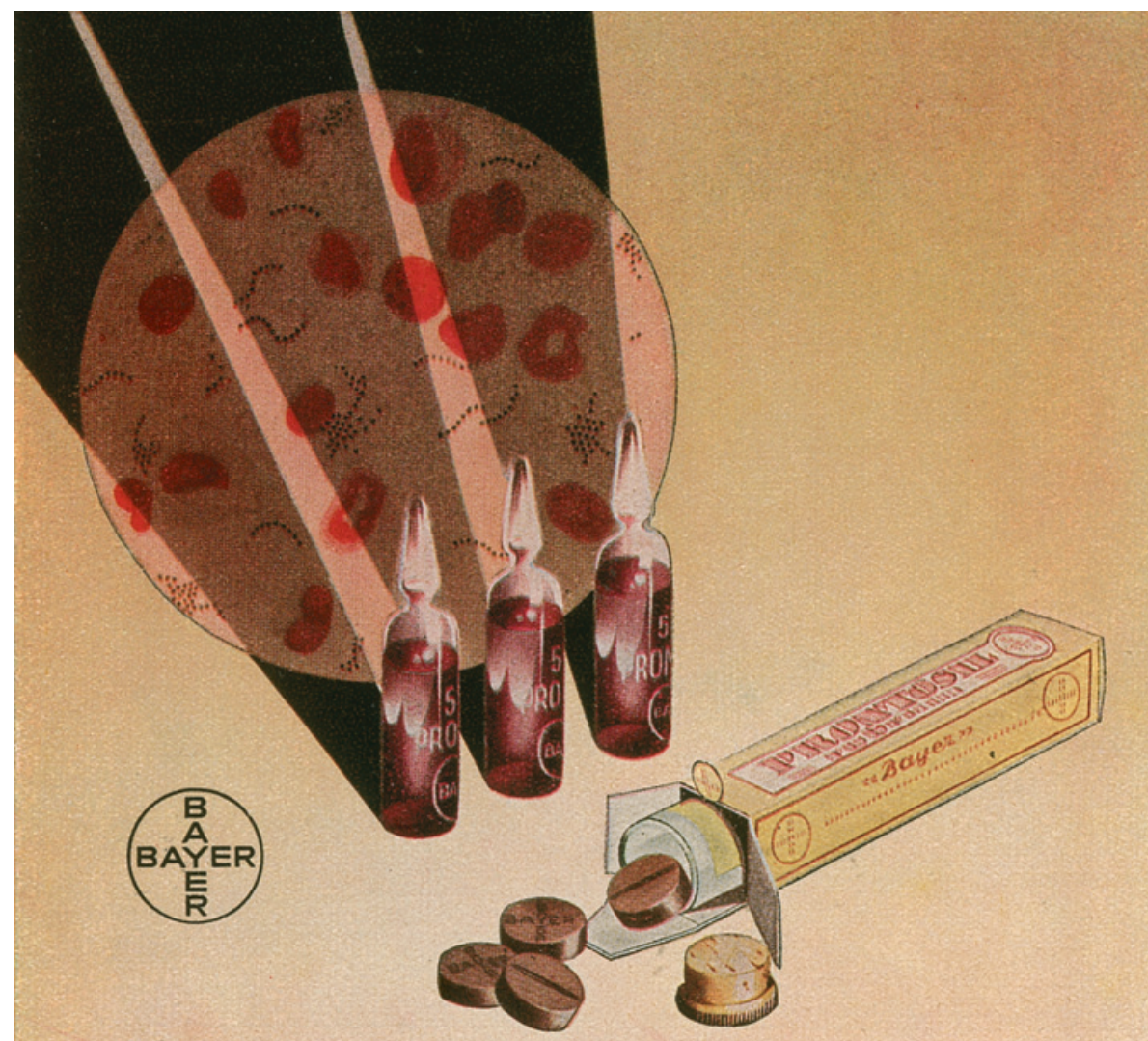

Med opfinnelsen av

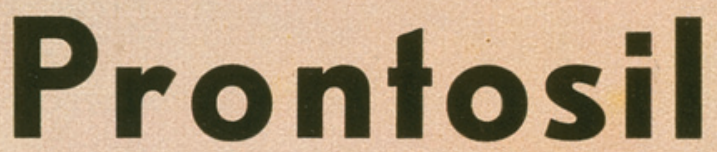

blev ikke bare det lenge søkte

kjemoterapeutikum mot streptokokker og andre sykdomsbakterier

funnet, men samtidig også det hittil uovertrufne topp-produkt.

Indikasioner: erysipelas, angina, sepsis, puerperalsepsis, cystiter, pyeliter, infekłartriter, meningiter, lymfogranuloma inguinale.

Videre profylaktisk før fødsler og operasjoner hvor man frykter infeksjoner.

Handelsformer: Prontosil tabletter. Prontosil oplosning $2 \frac{1}{2} \%$. Prontosil oplosning $5 \%$

Representasjon for Norge: NORRIGEFA A/S, Prinsensgate 2, OSLO 